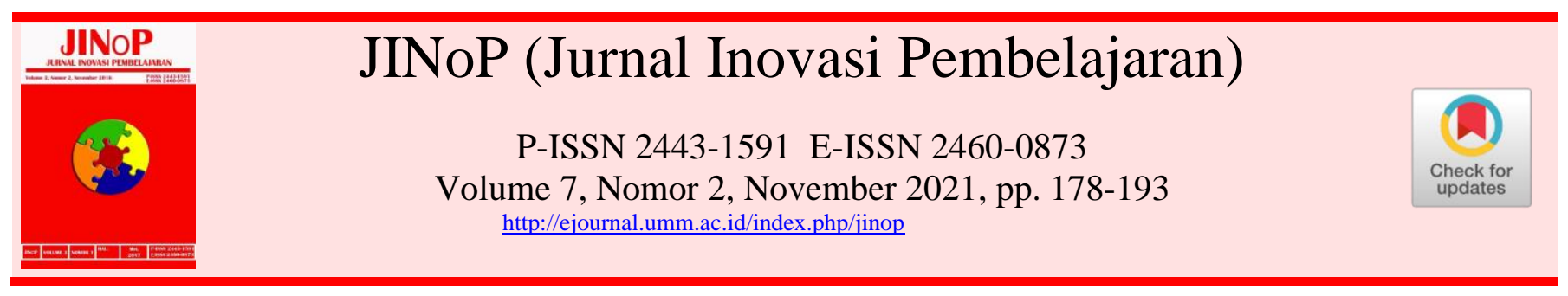

\title{
Praktikum jarak jauh pada perkuliahan Apresiasi Menghias Kain dengan Video Blog
}

\author{
Ratih Swastika Permata $^{1)^{*}}$, Wesnina Nawimar ${ }^{2)}$, Indro Moerdisuroso ${ }^{3)}$ \\ ${ }^{1}$ Program studi Pendidikan Tata Busana, Fakultas Tehnik, Universitas Negeri Jakarta, Jl. \\ Rawamangun Muka Raya No.11, Jakarta Timur, Indonesia \\ ${ }^{2}$ Program studi Pendidikan Tata Busana, Fakultas Tehnik, Universitas Negeri Jakarta, Jl. \\ Rawamangun Muka Raya No.11, Jakarta Timur, Indonesia \\ ${ }^{3}$ Program studi Pendidikan Tata Busana, Fakultas Tehnik, Universitas Negeri Jakarta, Jl. \\ Rawamangun Muka Raya No.11, Jakarta Timur, Indonesia
}

ratihswastikapermata@gmail.com *; wesnina@unj.ac.id ; indro@unj.ac.id

*Penulis Koresponden

\begin{abstract}
ABSTRAK
Pembelajaran daring pada Vokasi Tata Busana menemukan tantangan dalam penerapannya, terutama pada metode pembelajaran praktikum. Salah satu strategi yang digunakan adalah menggunakan video blog dalam proses penyampaian materi praktik. Penelitian ini bertujuan untuk memperoleh persepsi mahasiswa dalam pembelajaran yang memanfaatkan video blog secara daring, proses transmisi makna yang berlangsung, dan kelebihan dan kekurangan video blog. Partisipan berjumlah 5 orang dan narasumber berjumlah 1 orang. Metode pengumpulan data dilakukan dengan cara wawancara, observasi partisipasi dan studi dokumentasi. Metode yang digunakan dalam penelitian ini adalah metode kualitatif studi kasus yang dilakukan pada kelas Apresiasi Menghias Kain pada tahun ajaran 2020/2021. Hasil penelitian menunjukkan bahwa 1) persepsi positif dalam praktikum daring berkaitan dengan aspek belajar mengajar dan penyampaian materi dengan vlog dan persepsi negatif pada aspek keterbatasan jaringan internet dan sarana belajar mahasiswa selama pembelajaran daring, 2) proses transmisi makna didukung oleh komunikasi instruksional antara pendidik dan peserta didik, 3) kelebihan media video blog terdapat dalam aspek penyampaian isi konten yang mudah dipahami, sifat media yang fleksibel, dan repetitif digunakan selama daring sedangkan kekurangannya terletak pada tidak meratanya pemahaman mahasiswa, terutama pada kasus praktikum menyebabkan temuan yang berbeda. Dapat disimpulkan penggunaan video vlog dapat menjadi sumber belajar alternatif pada pembelajaran praktikum jarak jauh.
\end{abstract}

Kata Kunci: Media Pembelajaran; Praktikum Jarak Jauh; Video Blog.

\section{ABSTRACT}

Online learning in Fashion Design Vocational School finds challenges in its application, especially in the practical learning method. One of the strategies used in practicum is by using video blogs in the process of delivering a practical lesson. This study aimed to find student perceptions in learning that utilizes online video blogs, the process of transmitting meaning on distance learning, and advantages and disadvantages of video blogs. There were 5 participants and 1 source person. The methods of data collection were conducted by doing interview, participatory observation, and documentation studies. The method employed in this study was a qualitative case study method conducted in the Decorating Cloth Appreciation class in the 2020/2021 Academic Year. The results showed that: (1) There were positive perceptions in online practicums related to teaching and learning aspects and the delivery of material with vlogs, negative perceptions were found on aspects of internet network limitations and student learning facilities during online learning. (2) The process of transmitting meaning was supported by instructional communication between educators and students. (3) The advantages of video blog 
media were in the aspect of delivering easy-to-understand content, the flexible and repetitive nature of the media user online. The lack of video blog media lies in the uneven understanding of students, especially in practicum cases which often lead to different findings in practice. It can be concluded that the use of video vlogs can be an alternative learning resource in distance practicum learning.

Keywords: Learning Media; Distance Practicum; Video Blog.

diunggah: 2021/08/29, direvisi: 2021/11/11, diterima: 2021/11/26, dipublikasi: 2021/11/30

Copyright (c) 2021 Permata et al

This is an open-access article under the CC-BY license

Cara sitasi: Permata, R. swastika, Nawimar, W., \& Moerdisuroso, I. (2021). Praktikum jarak jauh pada perkuliahan apresiasi menghias kain dengan video blog. JINoP (Jurnal Inovasi Pembelajaran), 7(2). https://doi.org/10.22219/jinop.v7i2.17939

\section{PENDAHULUAN}

Sebagai langkah untuk meminimalisir penularan Covid-19 di masyarakat khususnya klaster pendidikan, pemerintah melalui Kementerian Pendidikan dan Kebudayaan (Kemendikbud) menerbitkan kebijakan dalam surat edaran tentang langkah pencegahan dan penanganan Covid-19 berupa proses belajar dari rumah atau disebut juga PJJ (Pembelajaran Jarak Jauh). Pelaksanaan pembelajaran jarak jauh (PJJ) didukung dengan penggunaan teknologi dan media yang terintegrasi oleh akses internet. Penggunaan teknologi mobile mempunyai sumbangan besar dalam lembaga pendidikan, termasuk di dalamnya adalah pencapaian tujuan pembelajaran jarak jauh (Korucu \& Alkan, 2011).

Pada pendidikan Vokasi Tata Busana, mata kuliah Apresiasi Menghias Kain adalah mata kuliah praktik yang memiliki bobot sebesar 3 SKS. Pada mata kuliah ini mahasiswa diharapkan memiliki kompetensi pengetahuan dan pemahaman tentang pengetahuan dan ketrampilan pembuatan berbagai macam teknik dekorasi pada tekstil untuk menghias busana, peralatan rumah tangga, dan kain. Praktikum pembelajaran Apresiasi Menghias kain sebelum pandemi dilakukan dengan cara dosen memberikan demonstrasi di depan kelas kemudian mahasiswa melakukan duplikasi tata cara serta tahapan yang dilakukan sesuai dengan instruksi. Ketika ditemukan kesulitan atau temuan-temuan mahasiswa dalam proses praktikum, peserta didik dapat langsung berkonsultasi dengan pendidik dan menyelesaikan temuannya. Pada tahap tersebut mahasiswa melakukan evaluasi yang berkaitan dengan penyelesaian masalah dalam proses praktikum. Proses evaluasi yang dilakukan dapat menjadi referensi penyelesaian temuan untuk praktik selanjutnya.

Kegiatan pembelajaran Apresiasi Menghias Kain yang dilakukan secara jarak jauh dilakukan dengan mengubah cara penyampaian materi pembelajaran dengan menggunakan media. Media berperan sebagai kesatuan antara lisan dan simbol untuk menyampaikan informasi dan menajamkan pemahaman kepada isi atau makna sebenarnya dalam pengajaran tersebut (Anwariningsih, 2011). Pendidik melakukan alternatif dalam menyampaikan materi kepada peserta didik. Alternatif media yang digunakan adalah media video blog (vlog). Vlog merupakan media komunikasi dan informasi berbasis video dan web yang mengkolaborasikan kreativitas, informasi, dan hiburan dalam satu hasil karya (Priana, 2017). Vlog yang memuat tutorial langkah praktikum yang dapat dipelajari di rumah. Pembelajaran dengan video yang bersifat tutorial telah dinyatakan efektif untuk meningkatkan hasil belajar peserta didik sebesar 82\% (Utomo \& Ratnawati, 2018). 
Penyampaian materi menggunakan video dapat menstimulasi peserta didik untuk lebih tertarik dengan materi pembelajaran dan dapat mengatasi kejenuhan dalam belajar. Media video yang bersifat audio visual juga dapat mengakomodasi tipe belajar peserta didik yang heterogen, seperti tipe auditif, visual, dan kinestetis karena dalam satu video dapat memuat aspek audio, visual, dan audio-visual (Mu'minah, 2021). Penggunaan media audio visual juga mendukung peserta didik untuk memperoleh pengetahuan, keterampilan, atau sikap yang digunakan untuk membantu tercapainya tujuan belajar (Hayati \& Harianto, 2017).

Video blog yang digunakan dalam pembelajaran daring Apresiasi Menghias Kain direncanakan dan dirancang oleh pendidik secara spesifik pada kompetensi yang akan dicapai pada mata kuliah, kemudian disebarluaskan melalui kanal youtube untuk dapat diakses oleh semua peserta didik. Pemanfaatan media youtube pada pembelajaran dalam jaringan diharapkan dapat menstimulasi minat peserta didik dalam memahami materi yang diajarkan (Setiawan et al., 2021). Video blog yang ditonton peserta didik secara berulang dapat membantu membimbing peserta didik untuk memahami materi praktik. Proses pembelajaran daring di kelas tetap berlangsung dengan mengkaitkan video blog yang telah dipelajari peserta didik dan proses diskusi serta evaluasi hasil praktikum yang diberikan pendidik.

Publikasi materi melalui kanal youtube dinilai sangat mendukung peserta didik dalam memahami materi, selain itu juga materi dapat diakses di mana saja, dapat diulang kembali, dan bersifat fleksibel. Proses menonton video yang dilakukan berulang dapat menstimulasi pengalaman peserta didik merasakan realitas kondisi yang sebenarnya dan memicu peserta didik untuk melakukan diskusi. Penggunaan video mampu mencapai $94 \%$ saluran masuknya pesan atau informasi melalui mata dan telinga serta mampu untuk membuat orang pada umumnya mengingat 50\% dari apa yang mereka lihat dan dengar dari tayangan program. Pesan yang diterima dari penggunaan media video juga lebih cepat diterima dibandingkan dengan media penyampai pesan lainnya (Berk, 2009).

Dalam pembelajaran Apresiasi Menghias Kain, terdapat beberapa kompetensi yang harus dicapai peserta didik, di antaranya adalah mampu merealisasikan materi pembelajaran menjadi hasil praktik sesuai indikator pencapaian kompetensi. Namun, dalam pelaksanaannya masih ada beberapa miskonsepsi dalam penyampaian antara materi praktikum yang disampaikan dengan praktik langsung yang dilakukan mandiri di rumah (temuan pada pra penelitian).

Penelitian terdahulu yang relevan dengan pemanfaatan video vlog dalam pembelajaran praktikum semuanya dilakukan pada mata kuliah teori di institusi pendidikan tinggi umum. Seperti penelitian yang dilakukan oleh Munirah dan Budiyono (2020) dalam penelitiannya yang berjudul "Pemanfaatan Media Video Blog (Vlog) Untuk Meningkatkan Keaktifan Dalam Mendampingi siswa belajar di rumah", penelitian ini mengungkapkan bahwa terdapat peningkatan keaktifan siswa dalam pembelajaran dirumah melalui media video blog (vlog).

Hal serupa dipaparkan oleh Muhammad Iqbal et. al. (2019), pada penelitiannya yang berjudul "Pengembangan video blog (vlog) Channel Youtube Dengan Pendekatan Stem Sebagai Media Alternatif Pembelajaran Daring" menyatakan bahwa media video blog (vlog) dinilai sangat layak digunakan sebagai media pembelajaran daring. Penggunaan media video yang diunggah ke kanal youtube juga memberikan motivasi dan pengalaman belajar peserta didik seperti 
yang dipaparkan oleh Mu'minah (2021) pada penelitiannya yang berjudul Pemanfaatan Media Pembelajaran Berbasis Video Sebagai Alternatif dalam Pembelajaran Daring IPA pada Masa Pandemi Covid-19. Sobron et. al. (2019) meneliti tentang persepsi siswa dalam studi pengaruh daring learning terhadap minat belajar siswa. Berdasarkan penelitian yang telah dilakukan, strategi pembelajaran daring learning dapat memperluas komunitas pembelajaran. Dengan pembelajaran daring learning, pendidik dapat lebih mudah menemukan ritme pelajaran yang tepat bagi siswa. Untuk mengetahui persepsi peserta didik pada pembelajaran daring praktik selama pembelajaran jarak jauh telah diteliti oleh Maulana (2020) yang menunjukkan bahwa persepsi mahasiswa terhadap pembelajaran daring pada mata kuliah praktik bersifat positif, dengan rincian aspek belajar mengajar sebesar 66,4\%, aspek kapabilitas (kemampuan dosen) sebesar $74,6 \%$, dan aspek sarana dan prasarana sebesar $72,7 \%$.

Sehubungan dengan penelitian relevan yang sebelumnya dilakukan penggunaan video blog dalam pembelajaran daring pada vokasi tata busana masih sangat sulit ditemukan. Hal ini dirasa penting difokuskan karena pendidikan vokasi berorientasi pada keterampilan sesuai dengan ilmu pengetahuan dan teknologi terapan sesuai dengan tuntutan kebutuhan lapangan kerja. Secara khusus program pendidikan vokasi diarahkan menguasai kemampuan dalam bidang kerja tertentu sehingga dapat langsung diserap sebagai tenaga kerja atau berwirausaha secara mandiri. Oleh karena itu, pengajaran pada program pendidikan vokasi disusun dengan lebih mengutamakan beban mata kuliah praktik/keterampilan dibandingkan dengan beban mata kuliah teori. Berkaitan dengan latar belakang yang dipaparkan peneliti tertarik untuk mengeksplorasi fenomena pemanfaatan video blog sebagai alternatif pembelajaran praktikum pada mata kuliah Apresiasi Menghias Kain dalam masa tanggap darurat Covid-19.

Penelitian ini bertujuan untuk untuk memahami suatu fenomena dari suatu subjek dengan menggali informasi yang berkaitan dengan tema penelitian secara mendalam. Studi kasus difokuskan dalam penelitian untuk mengkaji proses pemaknaan yang didapatkan peserta didik dari video blog dan pembelajaran praktikum pada prodi pendidikan tata busana di Universitas Negeri Jakarta. Fokus studi kasus lebih spesifik pada kanal youtube Wesnina Nawimar, pembelajaran praktikum daring di masa tanggap darurat Covid-19 dan mata kuliah tersebut yang secara unik dikaji khusus pada penelitian ini.

\section{METODE}

Jenis penelitian ini adalah deskriptif studi kasus karena fokus penelitian adalah mengkaji fenomena dan mengekplorasi pemanfaatan video blog yang erat kaitannya dengan pemaknaan yang tidak bisa diukur dengan angka dan membutuhkan inteprestasi mendalam. Metode ini juga dipilih karena kualitatif lebih mampu mendekatkan peneliti dengan objek yang dikaji.

Pendekatan penelitian yang digunakan adalah pendekatan kualitatif, pendekatan kualitatif lebih tepat digunakan untuk meneliti masalah-masalah yang membutuhkan studi mendalam, seperti pemanfaatan video blog sebagai alternatif pembelajaran praktikum mata kuliah Apresiasi Menghias Kain di masa tanggap darurat covid-19. Studi ini bersifat eksplorasi, jadi tidak bertujuan menguji hipotesis, atau membuat suatu generalisasi.

Sumber data penelitian yang digunakan adalah 5 orang peserta didik yang berperan sebagai informan untuk proses wawancara mendalam. Hasil praktikum 
jarak jauh yang dikerjakan oleh 5 orang peserta didik pada mata kuliah Apresiasi Menghias Kain yang menggunakan media video blog Wesnina Nawimar dalam pembelajarannya. Dokumentasi diskusi daring dalam forum kelas, meliputi proses pengerjaan tugas praktikum yang diunggah mahasiswa melalui media google classroom, komunikasi yang dibangun dalam proses pembelajaran yang diteliti dari komentar dan respon mahasiswa dan pendidik. Feedback atau umpan balik yang didapatkan pada kolom komentar dalam kanal Wesnina Nawimar.

Sesuai dengan salah satu ciri penelitian kualitatif yakni memperlakukan orang sebagai instrumen pengumpul data, untuk itu maka peneliti menjadi alat instrumen pengumpul data. Hal ini dilakukan dalam pengamatan berperan serta (Partisipation Observer), wawancara mendalam (In Depth Interview) pada peserta didik yang berperan sebagai partisipan, pemilihan partisipan dilakukan dengan prosedur bola salju (Bungin, 2007), pengumpulan dokumen, foto dan sebagainya. Ketika mengkaji pemanfaatan video blog sebagai alternatif pembelajaran daring mata kuliah Apresiasi Menghias Kain di masa tanggap darurat Covid-19, peneliti menggunakan self-report research, yaitu informasi yang dikumpulkan oleh peneliti sendiri.

Teknik analisis data yang digunakan adalah model interaktif Miles dan Hubermen. Data yang terkumpul disajikan dalam bentuk deskriptif, kemudian diuji keabsahan dengan triangulasi sumber data, yang bertujuan untuk mendapatkan kebenaran intersubjektif. Teknik Analis data yang dilakukan dalam studi kasus ini adalah menggunakan model interaktif Miles dan Hubermen (1984) (Gambar 1).

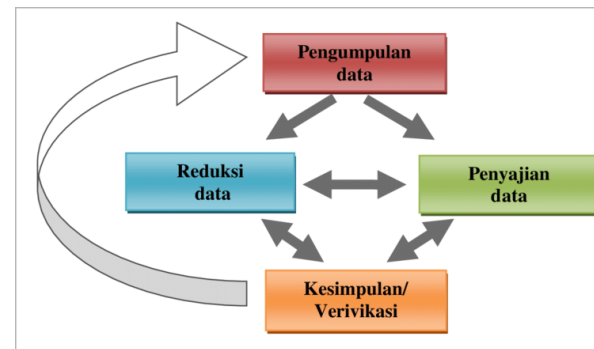

Gambar 1. Model Interkatif

Sumber: Miles dan Hubermen (1984)

Pada tahap ini, peneliti melakukan reduksi data dengan cara memilah-milah, mengkategorikan dan membuat abstraksi dari dokumentasi (Sugiyono, 2015). Pada penelitian ini peneliti mereduksi data menggunakan data yang didapatkan pada observasi partisipasi melalui keterlibatan peneliti secara langsung dalam kelas Apresiasi Menghias Kain, dan juga grup media sosial tempat berdiskusi juga mengamati video rekaman dalam konten youtube yang digunakan dalam pembelajaran jarak jauh. Proses analisis lebih lanjut setelah proses reduksi data. Setelah peneliti menarik kesimpulan kemudian akan dilanjutkan pada proses penyajian data yang nantinya menghasilkan sebuah tabel data. Dalam merancang tabel data dibutuhkan aktivitas analisis untuk mengelompokan data yang mana, dalam bentuk yang mana dan dimasukan dalam sel yang mana. Untuk memudahkan dalam pengelompokan, peneliti melakukan proses Coding, coding data yaitu proses pelabelan pada data yang dilakukan oleh peneliti sebagai proses analisa. Proses coding dilakukan dengan membuat kata, frase atau kalimat yang merepresentasikan aspek atau esensi dari data yang ditangkap peneliti (Saldaña, 2021). Proses penarikan kesimpulan akan menyajikan sesuai urutan fokus kajian dan temuan 
penelitian atau dengan mengikuti "logika" piramida terbalik. Artinya, aktivitas dilakukan dari atas ke bawah mengerucut semakin tajam, bukan dengan mengikuti "logika".

Uji keabsahan data dilakukan dengan melakukan triangulasi. Pada penelitian ini triangulasi data menggunakan triangulasi sumber data dan triangulasi waktu. Triangulasi data dengan sumber data yang dilakukan peneliti dilakukan dengan mengkonfirmasi data yang didapatkan dengan narasumber yaitu pendidik pada mata kuliah Apresiasi Menghias Kain, triangulasi data dilakukan di akhir penelitian ketika semua informasi sudah dipresentasikan dalam draft laporan, kemudian sebelum hasil penelitian dipublikasikan, peneliti dapat meminta informan untuk membaca kembali draft laporan penelitian itu. Langkah ini bertujuan untuk mengonfirmasikan berbagai informasi yang peneliti peroleh dari informasi lain atau sumber lain karena bisa jadi pada tahap ini masih ada perbedaanperbedaan informasi maupun pemaknaan informasi yang terjadi di antara berbagai sumber.

Selain triangulasi data dengan sumber data, peneliti juga melakukan triangulasi waktu. Triangulasi teknik untuk menguji kredibilitas ulang sehingga sampai ditemukan kepastian datanya (Sugiyono, 2010). Triangulasi data pada penelitian ini dilakukan dengan melakukan wawancara dalam waktu yang berbeda, wawancara dilakukan kepada partisipan setelah Ujian Tengah Semester dan setelah Ujian Akhir Semester pada mata kuliah Apresiasi Menghias Kain.

\section{HASIL DAN PEMBAHASAN Persepsi mahasiswa}

Persepsi mahasiswa dikaji dari pemanfaatan video blog selama pembelajaran daring. Video yang dikaji dalam penelitian ini bersumber dari kanal youtube Wesnina Nawimar, kanal youtube tersebut berdiri sejak 21 oktober 2016 dan secara konsisten mengunggah konten pembelajaran tata busana. Terdapat 120 video yang diunggah dalam kanal tersebut. Video dalam kanal Wesnina telah ditonton sebanyak 287.165 kali (data per 7 Agustus 2021) dan menarik antusiasme penonton untuk berlangganan atau melanggan kanal Wesnina. Terdata sebanyak 4470 berlangganan kanal ini.

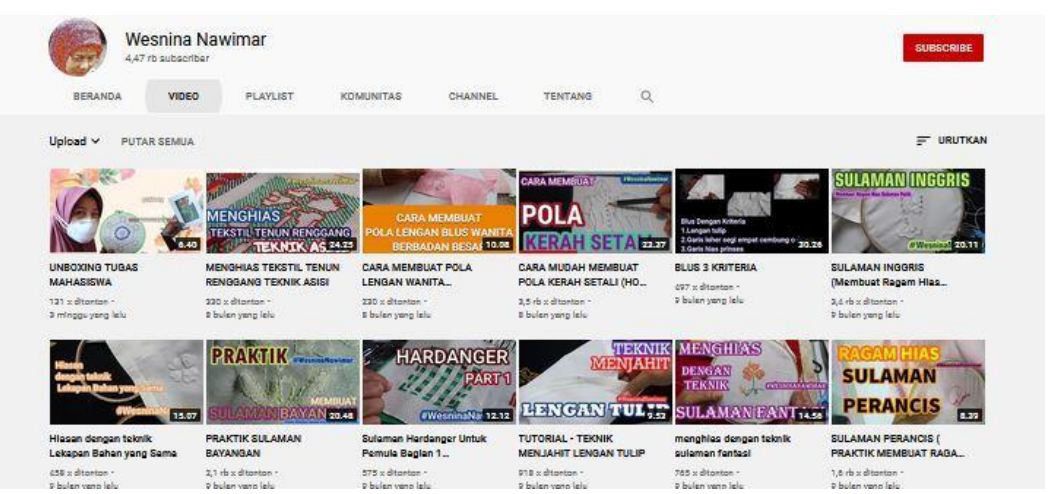

\section{Gambar 2. Konten pembelajaran dalam kanal Wesnina Nawimar}

Durasi rata-rata video yang diunggah dalam kanal youtube Wesnina berdurasi antara 10-20 menit (Gambar 2), lamanya durasi bergantung pada topik atau konten yang disampaikan.

Dalam satu konten atau video kanal Wesnina meraih tayangan sebanyak 3,5 ribu kali (Gambar 3), hal ini dapat menggambarkan antusiasme penonton dalam 
mempelajari konten atau materi tata busana yang disampaikan oleh kanal Wesnina Nawimar.

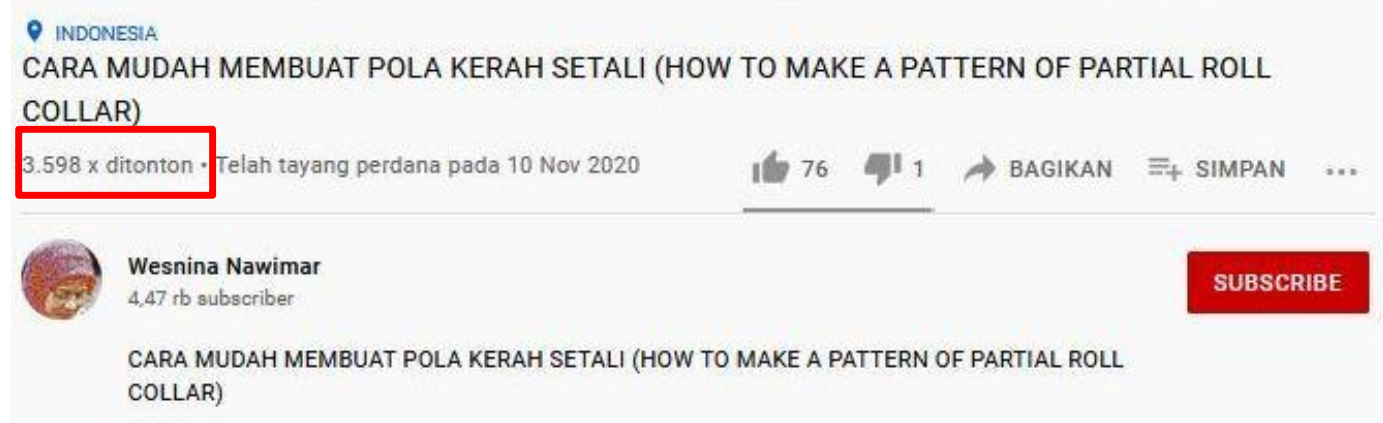

Gambar 3. Data total keseluruhan penonton pada satu tayangan video

Interaksi dalam penyampaian konten atau materi juga dilakukan secara dua arah pada kolom komentar (Gambar 4), pemilik kanal berupaya untuk merespon pertanyaan atau tanggapan para penonton yang mengulas materi yang disampaikan.

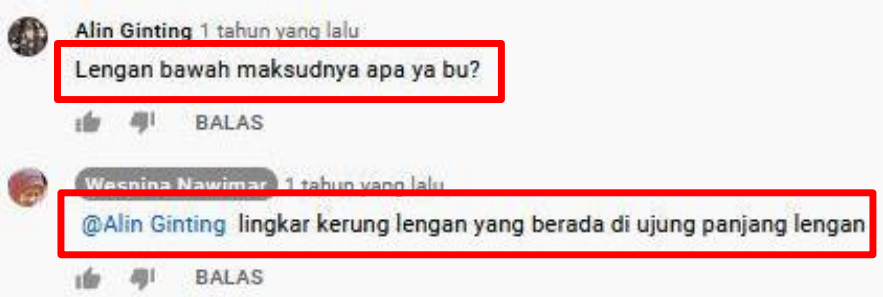

\section{Gambar 4. Interaksi pemilik kanal dengan penonton dalam mengulas materi}

Dalam pembelajaran mata kuliah Apresiasi Menghias Kain yang dilangsungkan secara daring, video dalam kanal youtube Wesnina Nawimar menjadi sumber belajar untuk menyampaikan materi praktikum, Kanal youtube telah dikaji sebagai solusi alternatif media pembelajaran mencoba menaikkan kualitas pengajaran dimasa pandemi Covid-19 (Sari, 2020).

Video yang di buat berjenis video blog yang umum dikenal dengan $v l o g$, berisikan tutorial atau tahapan proses pembuatan hiasan kain atau sulaman. Beberapa konten yang relevan dengan mata kuliah Apresiasi Menghias Kain diantaranya: berbagai teknik sulaman, penerapan desain hiasan pada tekstil, dan berbagai teknik hias tusukan.

\section{Hasil pengamatan observasi partisipan}

Observasi partisipasi merupakan sebuah teknik pengumpulan data yang mengharuskan peneliti melibatkan diri dalam kehidupan masyarakat yang diteliti (Fajrin, 2011). Observasi partisipasi pada penelitian ini dilakukan dengan cara ikut serta dalam pembelajaran Apresiasi Menghias Kain pada semester 114 yang dimulai dari bulan Maret hingga Juni 2021. Observasi partisipasi pada penelitian ini digunakan untuk memahami pandangan yang menyeluruh tentang fenomena yang dikaji di lapangan, temuan-temuan, mengidentifikasi karakteristik partisipan dan narasumber, serta hal- hal yang tidak terungkapkan oleh responden pada saat wawancara.

Kelas Apresiasi Menghias kain dilakukan secara daring setiap hari senin pada pukul 08.00-10.00 (Gambar 5). 


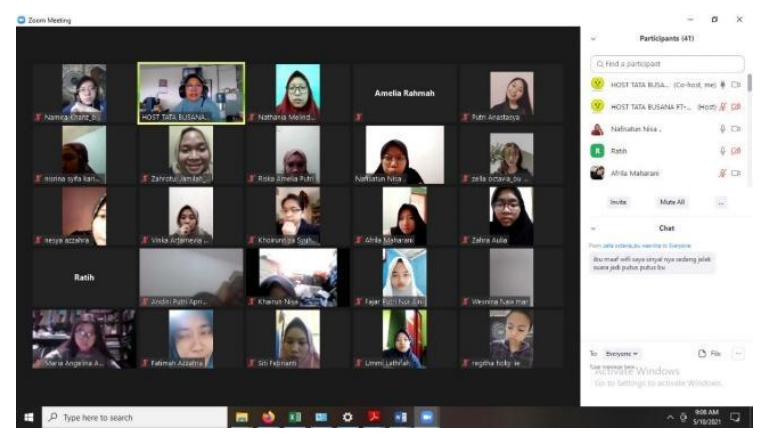

Gambar 5. Kelas Apresiasi Menghias Kain yang menggunakan media virtual meeting

Dari hasil pengamatan peneliti dalam melakukan observasi partisipasi, ditemukan bahwa penggunaan media video vlog digunakan untuk menyampaikan materi praktikum sulaman dan teknik menghias kain. Video vlog diunggah ke dalam kanal youtube Wesnina Nawimar dan kemudian link nya disebarluaskan dalam media komunikasi kelompok (whatsapp group) untuk memudahkan mahasiswa dalam mengakses video. Publikasi link materi melalui video dilakukan sebelum kelas berlangsung, sehingga mahasiswa dapat mempelajari terlebih dahulu materi yang akan disampaikan dalam kelas selanjutnya.

\section{Proses transmisi makna}

Proses transmisi makna dalam pembelajaran praktikum daring dengan video blog didukung oleh proses komunikasi instruksional, proses ini berlangsung pada kelas Apresiasi Menghias Kain yang berlangsung secara daring. Komunikasi instruksional merupakan persimpangan antara guru dan siswa, serta pertukaran makna antara guru dan siswa (Preiss \& Wheeless, 2014). Proses komunikasi instruksional dan transmisi makna dilakukan di kelas, dengan pendidik yang bertindak sebagai komunikator, peserta didik sebagai komunikan dan materi pembelajaran sebagai pesan (Thadi, 2019). Keberhasilan transmisi makna dalam komunikasi instruksional dipengaruhi oleh keahlian dan aspek pedagogik yang dimiliki guru serta kompetensi pendidik dalam aspek komunikasi pembelajaran, pendidik berperan sebagai pemberi instruksi dan peserta didik yang berperan sebagai penerima instruksi (Shintiyana, 2020). Komunikasi instruksional dalam pendidikan juga bertujuan untuk mendukung pendidik untuk memberikan kemudahan belajar melalui suasana belajar yang kreatif dan kondusif dengan cara menggunakan variasi media pembelajaran (Saleh \& Handayani, 2020).

Tatap muka pada kelas Apresiasi Menghias Kain dilangsungkan secara daring dengan menggunakan media google meet atau zoom, yang dihadiri oleh 50 mahasiswa, dari pengamatan penulis mengenai aktivitas tatap muka melalui google meet, terbagi dua skema yaitu tahap pembahasan dan evaluasi. Skema minggu pertama membahas tentang materi baru. Pada minggu pertama mahasiswa diberikan tugas praktikum sesuai dengan materi yang disampaikan, masa tenggang penugasan adalah selama satu minggu. Skema pada minggu kedua bersifat evaluatif, proses asistensi tugas berlangsung pada minggu ini, dimana mahasiswa menjabarkan konsep, ide atau desain sebelum diaplikasikan pada hasil praktikum. 


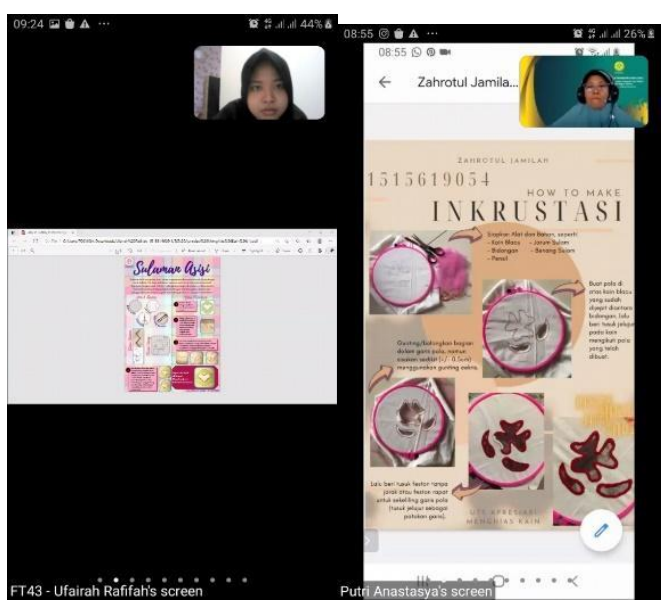

\section{Gambar 6. Presentasi tugas salah satu peserta didik secara daring}

Untuk tugas praktikum yang dikerjakan, mahasiswa diberikan kesempatan untuk menunjukkan hasil praktikumnya secara virtual dengan cara presentasi atau penjelasan singkat (Gambar 6), kemudian dilakukan diskusi mengenai temuan baru atau hambatan yang ditemui pada praktikum. Jika ditemukan kesalahan maka narasumber akan memberikan tanggapan. Pada kesempatan ini peserta didik lainnya dapat mempelajari secara khusus mengenai tipe serta solusi atas jenis permasalahan secara spesifik. Dengan strategi tersebut, pembelajaran daring memberikan kesempatan peserta didik untuk bertukar pendapat dengan orang lain dan memberikan kesempatan kepada peserta didik untuk belajar mandiri (Hwang et al., 2021).

Untuk beberapa peserta didik yang tugasnya belum sesuai dengan standar, diberikan kesempatan memperbaiki sesuai dengan saran narasumber. Dalam hal ini proses pembelajaran terjadi karena didukung keterlibatan berbagai komponen yang saling berkaitan dan saling berinteraksi (Pane \& Dasopang, 2017). Bukti atau produk aktivitas belajar dari rumah diberi umpan balik yang bersifat kualitatif dan berguna dari guru, tanpa diharuskan memberi skor/nilai kuantitatif (Arifa, 2020).

Hasil penelitian ini adalah transmisi makna dalam komunikasi instruksional yang diterapkan dalam mengajar peserta didik vokasi tata busana dilakukan secara verbal dan non-verbal pada pembelajaran jarak jauh. Komunikasi verbal berupa kata-kata yang sederhana dan istilah dalam keilmuan vokasi Tata Busana. Ditemukan juga beberapa simbol atau gambar yang yang muncul dalam video blog maupun dalam proses pembelajaran tatap muka virtual. Komunikasi non-verbal yang dilakukan berupa gerakan tubuh yang tampak pada video blog. Komunikasi nonverbal sendiri merupakan sebuah bentuk komunikasi lain di luar kata-kata verbal (Octavianti, 2016). Berkaitan dengan hal itu ditemukan juga komunikasi interpersonal. Yakni pendidik menyampaikan materi secara individual. Proses instruksional dalam pembelajaran daring diawali dari sesi pendahuluan, kemudian dilanjutkan dengan penyampaian materi. Kemudian, kegiatan instruksional diakhiri dengan kegiatan evaluasi, dimana pendidik melakukan penilaian terhadap siswa. Adanya pembelajaran jarak jauh secara daring akan menstimulasi peserta didik untuk memahami materi yang bersifat abstrak, mengembangkan pembelajaran kolaborasi, penalaran dan kegiatan pemecahan masalah (Arnott \& Yelland, 2020).

\section{Hasil wawancara mendalam (deep interview)}


Wawancara mendalam digunakan peneliti untuk mencari tahu pengalaman belajar dan persepsi mahasiswa pada saat dan selesai menonton video blog pembelajaran busana pada kanal Wesnina Nawimar, yaitu mencari informasi mengenai proses pembelajaran daring yang telah mereka lakukan pada mata kuliah Apresiasi Menghias Kain dan menggali potensi pemanfaatan video blog pada proses belajar.

Berdasarkan data wawancara mendalam yang dilakukan peneliti kepada peserta didik pada Angkatan 2019 di prodi Pendidikan Tata Busana, Universitas Negeri Jakarta diperoleh hal berikut:

1. Penggunaan video vlog dirasa sangat membantu memahami peserta didik mengerti, penyampaian materi praktik pun dirasa jelas.

2. Beberapa peserta didik terkendala pada beberapa klip pada potongan video dan sudut pandang pengambilan gambar pada proses sulaman.

3. Dari keseluruhan materi pembelajaran Apresiasi Menghias kain yang telah disampaikan dengan bantuan video vlog, sulaman racheliu adalah materi yang paling sulit dipraktikan di rumah, karena prosesnya yang rumit dan detail.

4. Peserta didik mengungkapkan bahwa kemasan materi dan cara penyampaian menggunakan video blog bersifat menyenangkan dan mudah diakses.

5. Pola komunikasi dan proses trasmisi makna pada pembelajaran daring yang dilakukan sangat membantu peserta didik memahami dan mempraktikan kembali materi yang disampaikan lewat video blog

\section{Hasil studi dokumentasi}

Studi dokumentasi dilakukan dengan mengumpulkan dan mengintrepretasikan objek visual yang menjadi temuan selama proses observasi berlangsung. Dokumen merupakan catatan peristiwa yang sudah berlalu. Dokumen bisa berbentuk tulisan, gambar, atau karya-karya monumental dari seseorang (Nilamsari, 2014). Dokumen yang digunakan merupakan data pendukung terhadap hasil pengamatan dan wawancara berkaitan dengan bentuk pesan verbal dan nonverbal dan juga hambatan-hambatan yang ditemui oleh peneliti. Contohnya seperti dokumentasi saat informan tengah melakukan komunikasi di video call. Studi dokumentasi bersumber dari tugas praktikum mahasiswa dan makalah yang berisi tahapan proses pembuatan karya, kemudian dikomparasi oleh penulis dengan rekaman video blog yang digunakan peserta didik untuk mempelajari teknik dan tahap pembuatan sulaman.

Berikut ini salah satu hasil praktikum yang dikerjakan untuk praktikum sulaman asisi, dokumentasi proses pembuatan sulaman asisi menjelaskan tahapan dari proses desain hingga hasil akhir. Ciri khas pada sulaman asisi adalah ragam hias dikerjakan dengan tusuk holben sehingga tampak garis siluet yang jelas pada tampilan permukaan ragam hias 


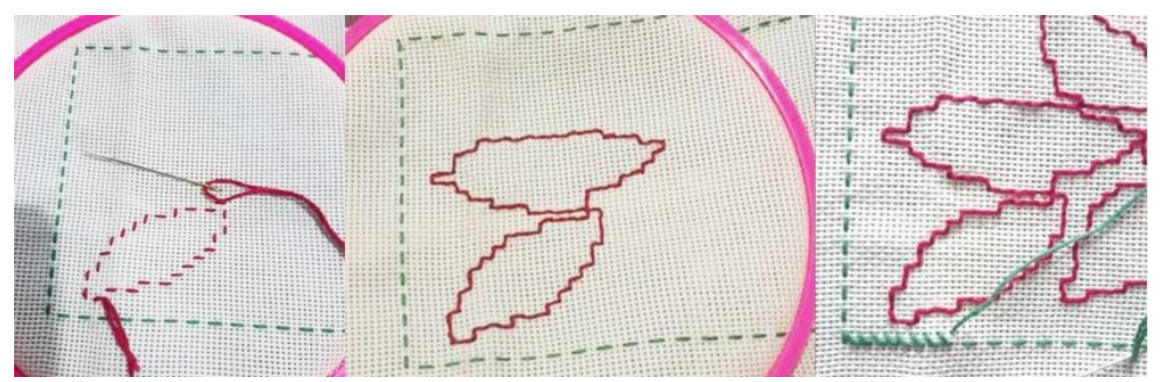

Gambar 7. Dokumentasi tahapan pembuatan sulaman asisi yang dikerjakan peserta didik

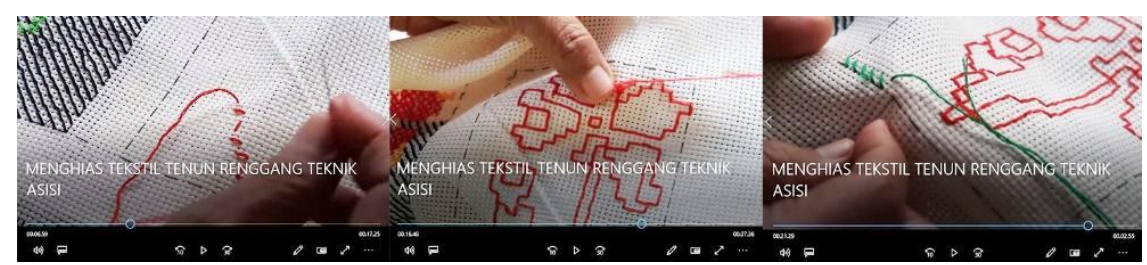

Gambar 8. Langkah proses sulaman asisi melalui video vlog

Gambar 7 menunjukkan tahapan yang dikerjakan peserta didik untuk menyelesaikan sulaman asisi, seperti yang diinstruksikan Ibu Wesnina dalam video Blog nya, langkah tusukan awal dimulai dengan menghitung lubang pada kain kemudian membuat jalur tusuk holben sesuai dengan pola ragam hias yang dirancang. Pada tahap ini peserta didik berhasil mengaplikasikan tahapan awal sehingga didapatkan tampilan tusuk holben yang benar dan rapi. Tahap selanjutnya adalah mengisi area diluar siluet ragam hias dengan tusuk silang yang diawali dengan posisi tusuk silang yang miring (benang berwarna hijau) (Gambar 8).

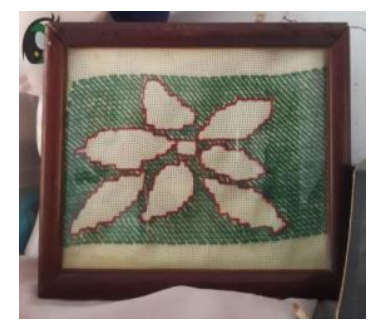

\section{Gambar 9. Hasil Praktik Sulaman Asisi oleh peserta didik}

Hasil praktik sulaman Asisi yang dikerjakan peserta didik sesuai dengan capaian kompetensi pada silabus Apresiasi Menghias Kain (Gambar 9). Peserta didik mampu mengaplikasikan tusuk holben dan tusuk silang serta membentuk siluet sulaman dengan rapi tanpa adanya serat benang yang terbuka.

Dokumentasi hasil tugas praktikum mahasiswa pada materi tenun punto tiranto, wujud sulaman terlihat bagian berlubang pada bagian depan yang merupakan ciri khas punto tiranto. 


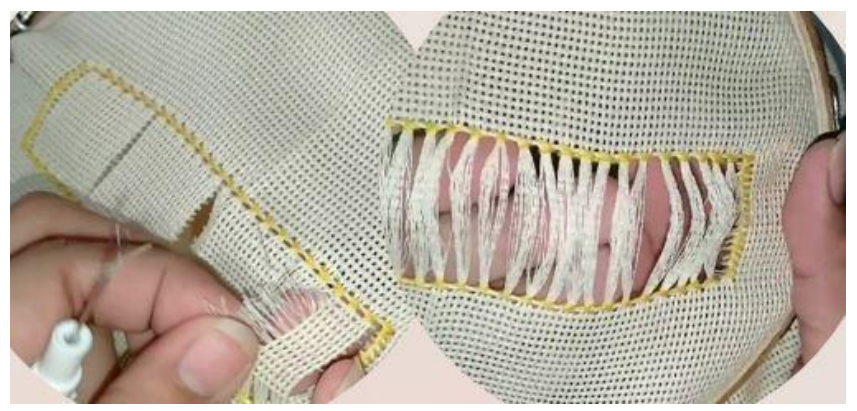

\section{Gambar 10. Dokumentasi tahapan pembuatan tenunan renggang (punto tiranto) yang dikerjakan peserta didik}

Pada fase mengeluarkan benang pakan terlihat peserta didik terampil dan sangat rapi memperhatikan sisi yang harus digunting sehingga hasilnya tidak ada lungsin atau pakan yang tertarik dan membentuk kerutan pada kain, tepian tusuk balut terlihat utuh dan tidak terpotong (Gambar 10). Permasalahan yang umum terjadi pada praktik punto tiranto adalah terpotongnya sisi tusukan balut yang telah dibuat di awal proses.

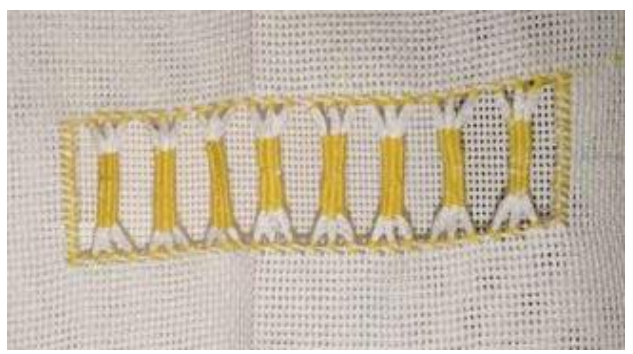

\section{Gambar 11. Hasil Praktik Tenun renggang punto tiranto oleh peserta didik}

Hasil praktikum tenun terawang punto tiranto yang diaplikasikan menjadi pouch serut dinilai sesuai dengan indikator capaian kompetensi yaitu mengaplikasikan dan mengkombinasikan tusuk balut dengan teknik anyaman dasar yang telah dipelajari pada kompetensi desain hiasan (Gambar 11). Teknik pengerjaan dan hasil praktikum mendetail dan sangat rapi sehingga disimpulkan materi punto tiranto berhasil tersampaikan dan dipahami peserta didik.

\section{Kelebihan dan kekurangan}

Berdasarkan hasil pengamatan, pemanfaatan video blog pada pembelajaran daring Apresiasi Menghias Kain menjadi alternatif solusi yang tepat untuk pembelajaran praktikum karena terdapat beberapa kelebihan, di antaranya:

1. Alur pemaparan demonstrasi materi praktik terlihat lebih terstruktur sehingga lebih mudah dipahami oleh peserta didik.

2. Aspek visual lain seperti teks dan gambar dalam video dapat memperkaya penyajian/penjelasan materi.

3. Pengguna dapat melakukan pengulangan pada bagian-bagian tertentu untuk melihat gambaran yang lebih fokus.

4. Kombinasi video dan audio dapat lebih efektif dan lebih cepat menyampaikan dibandingkan media teks.

5. Menunjukan dengan jelas satu langkah prosedural secara lengkap.

Namun, terdapat juga kekurangan yang muncul pada pemanfaatan video blog di antaranya 
1. Pembelajaran dengan bantuan video blog menuntut peserta didik untuk memahami dan mengolah materi secara individual, sehingga dibutuhkan waktu yang berbeda untuk memahami dan dapat mempraktikan kembali materi yang disampaikan.

2. Video youtube yang diunggah dalam kanal youtube membutuhkan kuota yang besar untuk dtonton, terlebih bersifat tutorial yang mewajibkan peserta didik untuk mengulang-ulang video dalam proses pembelajarannya. Kanal youtube telah dikaji sebagai solusi alternatif media pembelajaran mencoba menaikkan kualitas pengajaran dimasa pandemic Covid-19.

3. Proses perancangan video blog yang digunakan sebagai media pembelajaran daring membutuhkan waktu yang relatif lama dan keterampilan khusus.

4. Dalam proses perancangan video, dibutuhkan sudut pengambilan gambar yang terarah pada proses pengambilan gambar sehingga fokus video lebih maksimal. Pengambilan yang kurang tepat dapat menyebabkan timbulnya keraguan penonton dalam menafsirkan gambar yang dilihatnya (Daryanto, 2018).

Penelitian yang dilakukan, bukan penelitian yang pertama kali dalam mengkaji video blog sebagai media pembelajaran, Hal ini melengkapi penelitian yang dilakukan oleh Munirah dan Budiyono (2020) yang dalam penelitiannya berjudul "Pemanfaatan Media Video Blog (Vlog) Untuk Meningkatkan Keaktifan Dalam Mendampingi siswa belajar di rumah", penelitian ini memperkuat temuan sebelumnya bahwa terdapat peningkatan keaktifan siswa dalam pembelajaran dirumah melalui media video blog (vlog), temuan dalam penelitian menjelaskan bahwa, setelah pembelajaran menggunakan media video blog peserta didik lebih aktif berdiskusi untuk membahas berbagai temuannya dalam pembelajaran yang dilakukan secara mandiri di rumah, hal ini terlihat dalam diskusi kelas daring yang berlangsung secara jarak jauh. Selain itu hasil penelitian menunjukkan bahwa penggunaan video blog berhasil menstimulasi proses kognitif peserta didik dalam praktikum jarak jauh mata kuliah Apresiasi Menghias Kain. Hasil studi juga menemukan bahwa peserta didik mengungkapkan persepsi positif dan merasa materi yang disampaikan lebih bermakna dan jelas. Hal tersebut sesuai dengan penelitian yang dilakukan Erniwati et al., (2015) dalam penelitiannya yang berjudul Penggunaan Media Praktikum Berbasis Video Dalam Pembelajaran IPA Fisika Untuk Meningkatkan Hasil Belajar Siswa

\section{SIMPULAN}

Setelah dilakukannya penelitian dan kajian pada pemanfaatan video blog dalam pembelajaran Apresiasi Menghias Kain, dapat disimpulkan bahwa Penggunaan video vlog dalam kanal Wesnina Nawimar dapat menjadi sumber belajar alternatif pada pembelajaran praktikum jarak jauh yang membantu mahasiswa dalam mempelajari teknik dan penerapannya dalam tugas praktikum. Hal ini terlihat dari proses pengerjaan dan hasil karya tugas praktikum yang dinilai sesuai dengan kriteria ketuntasan dalam kompetensi dasar. Peserta didik menggunakan media video Blog Wesnina dalam menstimulasi proses kognitif dalam praktikum jarak jauh mata kuliah Apresiasi Menghias Kain yang didukung dengan komunikasi instruksional dalam diskusi virtual secara daring untuk menganalisis solusi atas temuan peserta didik pada praktikum mandiri di rumah. 
Peserta didik dapat merealisasikan materi yang disampaikan melalui video blog menjadi suatu hasil karya sesuai dengan indikator pencapaian kompetensi pada tiap materi dan indikator keberhasilan transmisi makna dalam video blog. Pendidik dapat memaksimalkan proses penyampaian materi praktikum yang berlangsung secara daring, video blog juga dapat dijadikan sumber belajar yang bersifat repetitif sehingga dapat dimanfaatkan pada tahun ajaran selanjutnya selama masih relevan dengan kompetensi dasar. Persepsi peserta didik dengan adanya pemanfaatan video blog.

Adapun saran yang diberikan adalah, dengan perkembangan keilmuan terapan keilmuan tata busana yang signifikan dibutuhkan pengembangan materi dan konten yang secara rutin diunggah sehingga antusiasme dan motivasi peserta didik lebih meningkat. Pemanfaatan video blog diharapkan dapat menjadi sumber inspirasi peserta didik dan pendidik dalam memaksimalkan pembelajaran daring tidak hanya pada mata kuliah Apresiasi Menghias Kain namun pada mata kuliah praktikum lainnya.

\section{DAFTAR PUSTAKA}

Anwariningsih, S. H. (2011). Unsur Estetika Dalam Perancangan Media Pembelajaran Berbasis Karakter Untuk Mata Pelajaran TIK Siswa Sekolah Dasar (SD). Jurnal Gaung Informatika, 4(2).

Arifa, F. N. (2020). Tantangan Pelaksanaan Kebijakan Belajar Dari Rumah Dalam Masa Darurat Covid-19. Info Singkat; Kajian Singkat Terhadap Isu Aktual Dan Strategis, XII (7/I), 6.

Arnott, L., \& Yelland, N. J. (2020). Multimodal lifeworlds: Pedagogies for play inquiries and explorations. Journal of Early Childhood Education Research, $9(1), 124-146$.

Berk, R. A. (2009). Multimedia teaching with video clips: TV, movies, YouTube, and $\mathrm{mtv} \mathrm{U}$ in the college classroom. International Journal of Technology in Teaching \& Learning, 5(1).

Bungin, B. (2007). Penelitian kualitatif: komunikasi, ekonomi, kebijakan publik, dan ilmu sosial lainnya (Vol. 2). Kencana.

Daryanto. (2018). Media Pembelajaran. Gava Media.

Erniwati, E., Eso, R., \& Rahmia, S. (2015). Penggunaan media praktikum berbasis video dalam pembelajaran IPA-Fisika untuk meningkatkan hasil belajar siswa pada materi pokok suhu dan perubahannya. Jurnal Sains Dan Pendidikan Fisika, 10(3).

Fajrin, M. (2011). Dinamika Gerakan Petani: Kemunculan Dan Kelangsungannya (Desa Banjaranyar Kecamatan Banjarsari Kabupaten Ciamis).

Hayati, N., \& Harianto, F. (2017). Hubungan Penggunaan Media Pembelajaran Audio Visual dengan Minat Peserta Didik pada Pembelajaran Pendidikan Agama Islam di SMAN 1 Bangkinang Kota. Al-Hikmah: Jurnal Agama Dan 
Ilmu Pengetahuan, 14(2), 160-180.

Hwang, G.-J., Wang, S.-Y., \& Lai, C.-L. (2021). Effects of a social regulationbased online learning framework on students' learning achievements and behaviors in mathematics. Computers \& Education, 160, 104031.

Iqbal, M., Latifah, S., \& Irwandani, I. (2019). Pengembangan Video Blog (Vlog) Channel Youtube Dengan Pendekatan Stem Sebagai Media Alternatif Pembelajaran Daring. Inovasi Pembangunan: Jurnal Kelitbangan, 7(2), 135.

Korucu, A. T., \& Alkan, A. (2011). Differences between m-learning (mobile learning) and e-learning, basic terminology and usage of m-learning in education. Procedia-Social and Behavioral Sciences, 15, 1925-1930.

Maulana, H. A., \& Hamidi, M. (2020). Persepsi mahasiswa terhadap pembelajaran daring pada mata kuliah praktik di pendidikan vokasi. Equilibrium: Jurnal Pendidikan, 8(2), 224-231.

Miles, M.B \& Huberman A.M. (1984). Analisis Data Kualitatif. Terjemahan oleh. Tjetjep Rohendi Rohidi. Penerbit Universitas Indonesia

Mu'minah, I. H. (2021). Pemanfaatan Media Pembelajaran Berbasis Video Sebagai Alternatif dalam Pembelajaran Daring IPA Pada Masa Pandemi Covid-19. Prosiding Penelitian Pendidikan dan Pengabdian 2021, 1(1), 1197-1211.

Munirah, M., \& Budiyono, A. (2020). Pemanfaatan Media Video Blog (Vlog) Untuk Meningkatkan Keaktifan dalam Mendampingi Siswa Belajar di rumah. Seminar Nasional Hasil Pengabdian Kepada Masyarakat, 4(1), 306-311.

Nilamsari, N. (2014). Memahami studi dokumen dalam penelitian kualitatif. WACANA: Jurnal Ilmiah Ilmu Komunikasi, 13(2), 177-181.

Octavianti, M. (2016). Komunikasi nonverbal proksemik di rumah tidak layak huni. Jurnal Kajian Komunikasi, 4(1), 10-27.

Pane, A., \& Dasopang, M. D. (2017). Belajar dan pembelajaran. Fitrah: Jurnal Kajian Ilmu-Ilmu Keislaman, 3(2), 333-352.

Preiss, R. W., \& Wheeless, L. R. (2014). Perspectives on instructional communication's historical path to the future. Communication Education, 63(4), 308-328.

Priana, R. Y. S. (2017). Pemanfaatan Vlog Sebagai Media Pembelajaran Teritegrasi Tekhnologi Informasi. Prosiding Seminar Nasional Pendidikan FKIP, 1(2).

Saldaña, J. (2021). The coding manual for qualitative researchers. Sage.

Saleh, A. M., \& Handayani, S. (2020). Komunikasi Intruksional dalam Konteks Pendidikan: Pandangan Barat, Islam, dan Nusantara. Inteligensia Media 
(Kelompok Penerbit Intrans Publishing).

Sari, L. (2020). Upaya Menaikkan Kualitas Pendidikan dengan Pemanfaatan YouTube sebagai Media Ajar pada Masa Pandemi Covid-19. Jurnal Tawadhu, 4(1), 1074-1084.

Setiawan, T. Y., Arsil, A., \& Noviyanti, S. (2021). Pemanfaatan Youtube Pada Sistem Pembelajaran Dalam Jaringan Masa Pandemi Covid-19 Di Kelas Iic Sekolah Dasar. Universitas Jambi.

Shintiyana, A. A. (2020). Komunikasi Instruksional Guru dalam Meningkatkan Keterampilan Sosial Anak Berkebutuhan Khusus di Sekolah Inklusif Galuh Handayani Surabaya. Commercium, 3(2), 1-11. https://ejournal.unesa.ac.id/index.php/Commercium/article/view/35773/3199 1

Sobron, A. N., \& Bayu, R. (2019). Persepsi siswa dalam studi pengaruh daring learning terhadap minat belajar ipa. SCAFFOLDING: Jurnal Pendidikan Islam Dan Multikulturalisme, 1(2), 30-38.

Sugiyono, D. (2010). Metode Penelitian Pendidikan Pendekatan Kuantitatif, Kulaitatif dan R \& D. Bandung: Cv. Alfa Beta.

Sugiyono, S. (2015). Metode penelitian kombinasi. Bandung: Alfabeta.

Thadi, R. (2019). Proses Komunikasi Instruksional dalam Pembelajaran Vokasional. JOEAI: Journal of Education and Instruction, 2(1), 49-55.

Utomo, A. Y., \& Ratnawati, D. (2018). Pengembangan video tutorial dalam pembelajaran sistem pengapian di SMK. Jurnal Taman Vokasi, 6(1), 68-76. 